\title{
'Read for Victory': Public Libraries and Book Reading in a British Naval Port City during the Second World War
}

Robert James, University of Portsmouth

In 1942 a library official in Portsmouth, UK appealed to the city's inhabitants to 'read for victory', believing that they had a duty to use their reading time productively as part of their wartime activities. This article argues that long-standing desires among the country's political and civic elites to encourage the nation's readers to spend their leisure time prudently intensified during the Second World War. The public library service was utilized by civic leaders, library officials and publishing trade personnel to aid the country's war effort. The article argues that negative attitudes regarding mass reading tastes remained largely static, despite recognition that the conflict drew people to the written word for relaxation and escapism. Using the naval city of Portsmouth as a casestudy, this article charts the activities of the city's public library authorities and the borrowing habits of its readers to reveal that while many people borrowed books in order to distract themselves from the conflict, the city's strategic importance ensured that many citizens also read in order to facilitate their preparedness for war service, whether that be on the home front or overseas. The article argues that while, in common with national trends, many of Portsmouth's citizens used libraries to obtain books to help distract them from the war, many remained eager to make use of the service for educational purposes, unlike the majority of the nation's library users, whose interest in this aspect of library provision rapidly waned as the war progressed. The article concludes that the public 
library service was viewed as a central plank in the war effort and that library officials worked continuously to ensure that it remained so.

'We have been urged to fight for victory, to dig for victory, and to save for victory. There can at least be no harm in suggesting that we read for victory. ${ }^{1}$

'Facing the Facts', The Portsmouth Reader, April 1940

During the Second World War people's preference for reading fiction as a form of escape from the stresses of daily life was gradually being accepted by a host of individuals who had previously criticized this type of reading as a form of popular entertainment. ${ }^{2}$ However, as the cited comments by the contributor to Portsmouth's library services inhouse magazine The Portsmouth Reader intimate, these same critics realized that reading could also be deployed for a more productive purpose. Instead of reading simply for entertainment and escapism, this contributor believed that library users could utilize the service for both educational and instructional reasons too. In fact, because Britain was embroiled in a harrowing war, this contributor recognized the important role Portsmouth could play in the conflict and argued that it was a duty - of both the public and members of the library service - to ensure that leisure time was used wisely, in pursuit of the greater good, thus echoing the views of other organisations, such as the Ministry of Information and the Army Bureau of Current Affairs, which believed that promoting the arts and traditional 'high' culture was a way of both celebrating and defending British culture during the conflict. ${ }^{3}$ This article will further advance understanding of the many ways in which British society was encouraged to participate in the war effort by revealing 
how reading was positioned as a means of social betterment and war preparedness. Using the naval city of Portsmouth as a case study, it will reveal that, despite some tolerance of the use of the leisure activity as a form of recreation only in order to keep morale steady, long-standing attitudes towards reading's edifying qualities continued to hold sway. It will thus demonstrate how nineteenth-century notions of 'rational recreation' held firm, with reading repeatedly employed as a means of instilling ideas of 'good citizenship' on the populace. Indeed, as Brad Beaven has noted, leisure had long been 'closely bound to narratives of social citizenship,' and this only intensified during the Second World War. ${ }^{4}$ The article argues that by exploring more localized experiences scholars gain greater appreciation of the role that civic cultures played in wartime, particularly when considering localities such as Portsmouth, where strong links with the country's armed services ensured that the city held special status.

The effects of the Second World War on Britain's home front have been well documented, with historians focusing on government intervention in public affairs and the impact of that involvement on the broader population. ${ }^{5}$ Less attention has been paid to the workings of local government, and even less has been written on local civic involvement in leisure institutions. ${ }^{6}$ Indeed, while many of society's wartime leisure activities have been well-researched by historians, particularly cinema-going and the propaganda role that film could play, very little has been written on the social function of reading during wartime, and nothing at all has been attempted on the role that public libraries were expected to play during the conflict. ${ }^{7}$ In fact, of what has been written on libraries and reading generally, none has focused specifically on Britain during the Second World War. ${ }^{8}$ The article thus redresses this imbalance to reveal how important 
public libraries and reading were (or were expected to be) to a population at war. It will demonstrate how public libraries were viewed as an essential 'war service', not just for providing instructional fare, but also for keeping the population's morale steady by providing a regular supply of fiction.

Deploying library services to educate sections of a nation's population was an aim shared by many individuals providing such services in wartime, not just in Britain, but internationally too. Ilkka Mäkinen has identified a similarly educational drive behind the introduction of hospital libraries in Finland during the war, while Terry Treachout has noted that America's Armed Services Editions programme - in which paperbacks were distributed to service personnel - had an equally vital part in, not just entertaining, but educating U.S. troops. ${ }^{9}$ Public librarians across Britain thus also expected the service to play a major role in aiding the war effort, but as this article will show, in strategicallyimportant locations such as the naval city of Portsmouth officials were even more determined to ensure the service was utilized appropriately, thus demonstrating that while all of British society was expected to participate in the war effort, some sections of it were required to play an even more significant role. ${ }^{10}$

The article will start by demonstrating how earlier ambitions surrounding the public library's purpose influenced civic elites in wartime. It will detail the ways in which library authorities, not just in Portsmouth, but across Britain, attempted to coordinate the service's activities in order to position it as a central plank of the war effort. How library officials and publishing trade personnel viewed society's wartime reading habits will also be explored in order to reveal that opinion remained static regarding the educational benefits of the written word, despite the accepted need to use 
leisure as a form of escape from the pressures of the conflict. The challenges of running a successful library service in wartime will then be explored, followed by an evaluation of society's book reading habits. The article will conclude by arguing that while, across the country, people's engagement with the written word was increasingly viewed as a key aspect of wartime citizenship, Portsmouth's strategic significance ensured that the reading activities of its inhabitants were considered to be even more crucial to the war effort. The article will demonstrate how important public libraries were expected to be as part of Britain's war effort by drawing on the extensive material held in Portsmouth's library archives, along with library archives elsewhere in the country, the MassObservation archive, and the publishing trade press.

\section{Public libraries as an educational service in peacetime and at war}

The expansion of the public library service in the twentieth century has long been viewed by historians as part of the ongoing drive by civic elites to instill the values of civic endeavour and good citizenship on to the country's library users. As David Vincent has noted, library authorities across Britain encouraged the purchase of 'good' books in an effort to mould the libraries' users into useful citizens. ${ }^{11}$ This was part of a wider trend, Jeffrey Hill argues, of using leisure as 'part of a grander mission to build a new human urban society of cultivated individuals. ${ }^{12}$ It is not surprising, therefore, to find that the 1927 Kenyon Report, which was compiled by a committee of the Board of Education, identified the public library as a means of achieving this, going so far as to call the service 'an engine of great potentialities for national welfare. ${ }^{13}$ Many of the country's public librarians agreed with this viewpoint. In Portsmouth, for example, civic officials 
believed that the public library played a key role in the city's educational and social life. ${ }^{14}$ Peterborough's public library officials, meanwhile, regarded the service as one which could 'contribute materially to economic progress as well as to individual enjoyment in life,' concluding: 'It is safe to say that no other British institution has such a potential for valuable service as the public library.' [emphasis in original] ${ }^{15}$ Public library usage was thus championed as a means of improving the nation long before the war started.

With such views widely held in the early-twentieth century, it is perhaps predictable to find that they reached fever pitch in the years following the outbreak of the Second World War. Indeed, both the Board of Education and Ministry of Labour sought to champion public libraries in wartime, suggesting that not just maintaining, but extending, the service was a crucial prop in the war effort. 'Public libraries,' one official claimed, 'afford recreation and instruction [and] relief from the strain of war work and war conditions' and were, therefore, of key importance in preserving the 'welfare of industrial workers. ${ }^{16}$ The Mass-Observation movement, whose survey into society's book reading habits in the early war period culminated in a two hundred page report in 1942, similarly recognised the importance of the public library in educating the mass reading public during wartime. 'It is impossible to over-estimate the importance of the library in determining the reading habits of Britain,' the report writer noted, adding:

Especially great is the importance of the public, municipally-owned library, for the least educated sections of the community. These people, many of whom still have unformed reading habits, the largest number of whom have an increasing level of education and interest, rely overwhelmingly on the public library for their 
sources of reading education, stimulation and relaxation. ${ }^{17}$

Across Britain, then, government officials, both local and national, recognized the benefits the public library service could play as part of the country's war effort. However, the importance of the service's role was even greater in port locations such as Portsmouth, where civic leaders, library officials, and the city's inhabitants, both fixed and transient, were drawn to the service in order to facilitate their preparedness for the war.

As a garrison town, home to both the army and navy, Portsmouth was considered to be of strategic importance, and during the war was described as a 'front line city.' 18 Indeed, Ordnance Survey maps of the period reveal that approximately 20 per cent of the available land was occupied by Royal Naval installations. ${ }^{19}$ Portsmouth was thus a notable military target for the German forces, and between July 1940 and May 1944 the city experienced 67 air raids, three of which - in August 1940, January 1941, and March 1941 - were particularly devastating to its infrastructure. ${ }^{20}$ The loss of major civic features to the German Luftwaffe - such as the Guildhall in January 1941 - has been argued to have led to a serious loss of morale among the city's citizens. ${ }^{21}$ Not surprisingly, then, attempts were made by Portsmouth's civic elites to try to bolster the mood of the citizens. Indeed, ensuring that life continued as normally as possible was one of the key aims of the nation's civic bodies when challenged by wartime conditions, and the response of Portsmouth's civic leaders was no exception. ${ }^{22}$ Portsmouth's library authorities thus repeatedly reported that the bombing raids would not prevent their service from carrying on as normal. Indeed, as early as January 1940, the editor of The 
Portsmouth Reader heavily criticised other local authorities for adopting what were believed to be 'panic measures' by closing or curtailing the activities of their libraries after war had broken out. ${ }^{23}$ As 'an absolutely essential service,' the editor noted, public libraries were central to the war effort. ${ }^{24}$

Interestingly, while Portsmouth's civic leaders championed the public library service during wartime, they had not always been quite such avid supporters of it. Indeed, despite the size of the city's population, which stood at around 250,000 in the period under review, Portsmouth's first public library did not open until 1883, much later than most other sizeable cities in England. ${ }^{25}$ There appears to have been an initial reluctance among the city's civic elites in setting up a free library service, with the local newspaper reporting in 1944 noting that 'in the early days of the [free library] movement Portsmouth was not "library conscious". ${ }^{26}$ However, after the first public library proved to be a wellliked and much-visited amenity, Portsmouth's civic leaders embarked upon providing branch libraries in many other areas of the city, including in the highly-populated working-class areas of Fratton, Kingston and Portsea, as well as in the more middle-class enclaves of Milton, North End and Southsea. ${ }^{27}$ In addition, during the 1930s the library committee launched a quarterly magazine, The Portsmouth Reader, which aimed to keep established readers up-to-date with new developments in the library service, while simultaneously promoting it to the population as a whole. ${ }^{28}$ By the Second World War, then, Portsmouth can be said to have been 'library conscious,' with six public libraries accommodating over 60,000 registered readers - almost a quarter of the city's population - who between them were borrowing more than a million books annually. ${ }^{29}$ How those library visitors made use of the services on offer, however, was often a bone of 
contention. Indeed, as mentioned, the public library service's expansion in the twentieth century continued the 'rational recreation' ethos of the previous century, so it is not surprising to find that library officials championed their service for its educational and instructional qualities rather than its purely recreational uses. In fact, by the 1930s Portsmouth's library officials were encouraging the service's users to choose more edifying fare than the usual fiction staples by reducing the range of what they identified as 'light' fiction titles in their libraries and reproducing lists in the local newspaper that contained details of more educational or instructional books that could be borrowed from the city's libraries. ${ }^{30}$

Portsmouth's public library authorities were not alone in desiring a reduced stock of fiction in their libraries. Such an aversion towards the inclusion of fiction, particularly 'light' fiction - such as the mysteries of Edgar Wallace and romances by Ethel M. Dell in public libraries was common nationwide. Indeed, E. Walton Marston, editor of the publishing trade's major paper, The Publishers' Circular and Booksellers' Record, echoed the views of many of the paper's readers when, in October 1932, he argued that public libraries should be 'directing, influencing or leading the public taste in reading towards books of an educational and uplifting character. ${ }^{31}$ The vast number of letters and leading articles that appeared in the trade paper criticizing both the stocking of fiction in public libraries and the public's appetite for it illustrates an unambiguous preference among publishing trade personnel towards the use of public libraries for more edifying purposes. Many public librarians concurred with these views, including Eric R. Stone, librarian at Fulham's Central Library, who noted: 
I can see no reason why an institution whose function is primarily educational should endeavour, to the detriment of its own foremost obligations, to enter into vain competition with the cinema and twopenny libraries as a peddler of mental opiates $[\ldots]$ I cannot agree [...] that they should cater for the complete lack of taste reflected in "A mystery and a love story please". Let us remember that as librarians, it is our duty not to tamely accept and cater for lack of taste, but to rectify so sad a condition as speedily as we may. ${ }^{32}$

Stone's comments underline the strength of feeling among most public librarians towards both the inclusion of fiction in the country's public libraries and the continuing popularity of the same among the reading public.

Indeed, it was only at the start of the Second World War when a growing number of letters appeared in the trade paper that suggested a more tolerant stance was being taken. The stresses of the conflict had seemingly caused a slight change of heart among the trade paper's contributors, for some now championed the reading of 'light' fiction as an ideal form of escape from it. One contributor to the discussion, Frederick J. Cowles, chief librarian of Swinton and Pendlebury public library service, had in fact been a highly vocal supporter of the inclusion of fiction in public libraries for some time. ${ }^{33}$ However, he took the opportunity afforded to him by this wartime softening of attitudes to promote his beliefs again, observing in October 1939:

[I]t is not easy to assess exactly what the public shall want. The only thing we can be sure of is that quantities of cheap fiction will be required, and so the bread and 
butter of publisher and bookseller is assured. We can be sure of this. The soldier will carry a book in his kit-bag, the civilian will keep books for his fireside, the child will learn the delights of literature. We are a nation of readers, and the war is only going to increase the demand for books. So publishers, booksellers, writers and even librarians can count upon a busy time ahead. ${ }^{34}$

Cowles's comments were widely supported. Indeed, other contributors wrote to the trade paper a few weeks later to make known their support of Cowles' stance. 'Escape books are needed,' one contributor commented, adding:

[People] agitated by depressing home conditions will want to find a means of escape into the realms of gold, and it will be up to publishers to find the writers who can turn out quickly the sort of stuff the public is needing. [...] There is a great need for a heroic character of the Bulldog-Drummond-cum-Saint-Hannay variety. [...] Sentimental stories with the hero in the ranks and his little sweetheart left to work in the munition factory will also be needed to fulfil the requirements of the feminine readers who are finding the two-penny magazines have been getting smaller and they need more literature, so have started to borrow library books. ${ }^{35}$

While these sentiments were echoed by local librarians across the country, including in Portsmouth where an editorial in The Portsmouth Reader noted that the war had caused a 'swing over to light reading' - a swing that was now viewed as 'sound 
commonsense' rather than, as it had been previously, a 'matter of regret' - there remained a nationwide drive to ensure the service was principally used for its educational and instructional opportunities. ${ }^{36}$ Publisher George Allen and Unwin Ltd, for example, wrote to the editor of The Publishers' Circular and Booksellers Record in December 1939 arguing that while they recognized the reading public 'do indeed want to escape from the war,' they believed 'the suggestion that light fiction affords the only, let alone the best, means [was] an illusion. ${ }^{37}$ A public library official in Derby, meanwhile, responding to the threat of library closures due to the risk of enemy bombing, argued that they be kept open because they served 'two useful purposes' in wartime: 'the collection and dissemination of information, and the maintenance of the morale of the public by preserving recreation and educational facilities. ${ }^{38}$ While recreation was duly noted by this library official as an important aspect of the library service, it was the service's educational and instructional opportunities that were more heavily championed.

Of course, as people of business, whether commercial or public-minded, publishers, booksellers and librarians astutely identified the opportunities the war afforded them. Indeed, in a leading article published just after the outbreak of war, the editor of The Bookseller duly noted the positive effect the conflict was likely to have on the book trade. '[P] eople's need for books will be greater than it has ever been before,' the editor noted, adding:

With cinemas and theatres closed, with sports meetings cancelled and other recreational outlets unavailable, with the wireless programmes consisting largely of news bulletins and official announcements, it is to books that men and women 
will turn for recreation and solace. ${ }^{39}$

In his year-end report at the close of 1939, the editor of The Publishers' Circular and Booksellers Record likewise recognised that '[t]he absence or restriction of many of the normal forms of entertainment has centred attention on the kind of interest and recreation available by the fireside in the form of books. ${ }^{40}$ While the editor noted that paper shortages ensured the production of books had decreased, he reported that book buying and borrowing had increased, with ' $[\mathrm{m}]$ any booksellers and librarians $[\ldots]$ experiencing demands beyond the normal,' and confidently added that 'this tendency is likely to increase. ${ }^{41}$ The growth in book sales and borrowing was confirmed by MassObservation. The organization found that public librarians benefited most from these changes, noting that the service had witnessed a 'marked increase' in borrowing since the start of the war. ${ }^{42}$ Despite the constraints placed upon the book trade, then, the numbers of people reading books had not been duly affected by the war. ${ }^{43}$ In fact, these investigations revealed that, at times, wartime conditions actually boosted the leisure activity's popularity. ${ }^{44}$ As in the pre-war period, though, how those readers utilized the public library service, and what books they chose to read, came under continued scrutiny. In fact, in this period of intense social dislocation and emotional anxiety, the reading habits of the country's public library users can be argued to have been subjected to even greater scrutiny, with calls being regularly made for libraries to be used for their original edifying purposes.

Indeed, Mass-Observation's research, drawn from studies at 47 libraries located across the country (although most were situated in and around the capital), revealed that 
public librarians recognised the intellectual value of the service they offered while the conflict was ongoing. As one librarian told a Mass-Observer:

In these days, when many intellectual activities cannot function normally, the work of the public library becomes more important. Books can be read in lunch hours, on buses, and at other times when most intellectual activities are impossible. So it is not surprising to find that issues from public libraries have on the whole maintained their pre-war figures, while in many cases record figures have been reached $[\ldots]$ The loss of many library members through various forms of national defence has been more than counterbalanced by the increased reading done by housewives in the absence of their husbands and sons, trainees studying technical literature, members of the civil defence and other services, and, above all, by those for whom other forms of intellectual recreation are no longer possible. $^{45}$

The librarian's thrice repeated use of 'intellectual' underlines the preferred usage of the service among the country's public librarians. Time and again, civic leaders and library officials chose to promote reading as an activity that could have educational benefits; benefits that were claimed to be central to the country's war effort. In Portsmouth, for example, library officials suggested a number of ways in which the service could be utilized, particularly in terms of how technical and instructional books could be used to aid war readiness among the high proportion of people who were engaged in war work in the city. ${ }^{46}$ 


\section{Challenges and changes to wartime library services}

A major factor for civic leaders and public librarians, of course, was determining how to continue providing a library service during the conflict. Along with the loss of personnel for war service, Mass-Observation noted that library authorities faced multiple and varied challenges. In urban areas many female and child readers were lost due to evacuation, while in rural locations the number of these borrowers increased. ${ }^{47}$ Meanwhile, the blackout, bombing raids and wartime working conditions all affected society's reading habits. ${ }^{48}$ The strategic importance of Portsmouth as a 'front line city' ensured that these challenges were heightened, but they also provided opportunities. While many mothers and children left the city, a large number of workers - female and male, civilian and military - were brought in to keep the city's war industries functioning. ${ }^{49}$ Portsmouth's reading public may have demographically altered, but the actions of the city's library authorities demonstrate that they worked hard to overcome any difficulties they faced. For example, to aid the provision of books in blackout conditions, elderly and infirm readers were supplied with 'supplementary tickets', while other readers were provided with additional 'temporary tickets' so they could obtain a greater number of books. ${ }^{50}$ In fact, while there were instances when the service was temporarily disrupted - during bombing raids, for example - overall the service continued much as it had done before the war, with stock levels remaining high and being regularly replenished. Indeed, each edition of The Portsmouth Reader included a section listing the range of books being purchased for the city's libraries - divided into various categories, such as 'Fiction' (always the largest), 'Literature' (which included 'classic' authors), 'Books for Boys and 
Girls', 'Applied Science' and 'Action' - and there is no discernable difference between the number or range of listings in the pre- and wartime periods. ${ }^{51}$ The main difference, of course, was in how the authorities expected the service to be used.

Across the war period, Portsmouth's library officials provided guidance on how the service could be employed to prepare the city's population for the task ahead. For assistance in their venture, library officials corresponded with the Ministry of Information, the government department chiefly responsible for publicity and propaganda in wartime, reassuring the Ministry's personnel about the service's role in disseminating information to the public. ${ }^{52}$ So successful were Portsmouth's library authorities at ensuring the service was well used during the early days of the conflict that they received a letter of praise from the Director of Home Publicity at the Ministry, Professor John Hilton, for their exceptional work. 'The war is shaping for a war of nerve-strain as well as of armed might and economic pressure,' Professor Hilton noted, adding:

The enemy is characteristically trying by every device of propaganda to infect our minds with the dry rot of doubt and discontent, in the hope that when the real testing time comes our morale will crumble [...] We must continue to inform ourselves upon the issues that underlie the conflict and upon what is at stake. We must learn, so far as we can, to interpret the course of world events. To this end books well chosen are indispensable. The Portsmouth Public Libraries are rendering signal service to the National Cause by providing the matter and the method of good reading. More power to them. ${ }^{53}$ 
In addition to Professor Hilton's letter of commendation, Portsmouth's library authorities also received praise from the Board of Education and Ministry of Labour regarding the service's wartime role. ${ }^{54}$ One leading national weekly publication, meanwhile, was also said to have reported that the authorities' activities had ensured 'Portsmouth City Libraries possessed a "sturdy independence of character". ${ }^{55}$ Portsmouth's library officials' promotion of the service as central to the city's wartime activities had thus become a highly successful enterprise.

The city's port-side location undoubtedly played a key role in shaping how the library service was operated and used. This is never more evident than in the many attempts made by library officials to encourage members of the armed services to use the libraries' facilities. In fact, time and again officials gave these transient communities special dispensation in order to allow them to borrow books, while also offering them assistance regarding the reading material they may have required ${ }^{56}$ In July 1940, for example, officials noted of the growth in demand for books in the 'applied science section': 'In many cases it is serving members of H.M. Forces who are seeking the information, many of them not attached to the city normally, but the service of the shelves has been extended to all such with the minimum of formality. ${ }^{57}$ Officials boasted that, of the public libraries located across the country, 'Portsmouth was amongst the first to offer library facilities to members of the Services,' and they were keen to remind borrowers from those services that their reading needs would remain 'consistently under review' for the war's duration. ${ }^{58}$ The authorities' attempts at coordinating the library service's activities in wartime in order to allow members of the armed forces to use the facilities were highly successful and, in October 1941, library officials were delighted to 
report in their in-house magazine that '[a]1l ranks and all branches of the Services continue to make full use of the stock. ${ }^{59}$

In addition to attracting members of the armed forces, Portsmouth's public library officials also reported drawing in borrowers from other government departments, along with civilians who were eager to help in the war effort. In April 1942, for example, it was confirmed that 'important and far-reaching use' was being made of the library stock by government officials. ${ }^{60}$ Tellingly, the library officials' distaste for the reading of 'light' fiction crept in, for it was duly noted that the variety of books borrowed - with titles ranging from Radio Communications to War Wounds and Fractures - 'hardly suggest light reading as a relief from war strains. ${ }^{61}$ Indeed, Portsmouth's library officials were proud to note that the borrowing of instructional and educational books continued throughout the war period and, in July 1943, boasted again that they had established 'working links' with 'the three services' while 'co-operative work [had] been undertaken with the Ministries of Agriculture and Fisheries, Information, Health and Supply. ${ }^{62}$ Reflecting on their wartime role later that year, library officials once more reported that 'many members of the Services have sought assistance in connection with their technical training problems and this also holds good for those many civilians who have taken up unfamiliar tasks. ${ }^{63}$ Portsmouth's library officials were thus reaching out to the city's population, both fixed and transient, to ensure the libraries they controlled were made good use of during the war.

In fact, in addition to their fixed-site facilities, Portsmouth's librarians also set up 'circulating' library vans that distributed books to 'isolated groups' working in a variety of locations across the city, such as gun-sites and searchlight stations ${ }^{64}$ While much of 
the material loaned at these sites consisted of 'light' reading, officials noted that, of the nine hundred books in circulation, 'nearly 200 volumes [were] devoted to more serious topics,' adding somewhat triumphantly, 'and they are all used. ${ }^{95}$ Portsmouth's library service was thus being well-used by members of the armed forces, government officials and civilian personnel, and it was seen to be playing a key role in the war effort, as had been intended. Interestingly, the widespread lending of instructional and technical books in wartime had caused something of a stir at the beginning of the conflict, principally regarding the type of information they made available to anybody who borrowed them. In a leading article in The Publishers' Circular and Booksellers' Record in December 1939, for example, the editor called for greater control of technical books because he argued that if they fell into the wrong hands they would aid the enemy. ${ }^{66}$ Nonetheless, the benefits to the war effort that the increased availability of instructional material allowed was also recognised and, as the work of Portsmouth's library authorities reveals, most public librarians were only too pleased to find their libraries were being used in the edifying way they had desired when the service was initially established.

As the war drew to its latter stages, Portsmouth's library officials - perhaps concerned about the level of funding available to them in the local government's reconstruction plans - began to employ their in-house magazine to publicize the importance of the service postwar. In an article entitled 'They Planned a World', published in January 1944, library officials drew attention to the role the service could be expected to play in postwar reconstruction. In a section recommending books for the 'new world', officials listed a variety of titles that could aid future development, including G.D.H. Cole's The Means to Full-Employment, Hans Heymann's Plans for 
Permanent Piece, and Valerie Heywood's Rebuilding Europe $6{ }^{67}$ In July the same year, officials reported on a national campaign, addressed in both the McColvin Report ${ }^{68}$ and the proposals of the Library Association, that focused on the role of public libraries in the postwar period, and argued that libraries should be regarded as 'the focal point of the community's cultural and informational activities. ${ }^{69}$ Early in 1945 , meanwhile, Portsmouth's library officials published an article entitled 'The Restless Continent' in which they noted, 'we must know a good deal more than we do now if we are to discuss European problems intelligently,' and followed the article with a list of History books on various European countries in order for library users to become more knowledgeable about the history, and therefore future development, of continental Europe.$^{70}$ Later the same year, and again clearly recognizing the changing attitudes towards world affairs, officials included an article on the continuation of the British Empire, noting that ' $[\mathrm{w}] \mathrm{e}$ all know of the British Empire; but how much do we know about it,' and again recommended a series of books on the 'study of Empire affairs' for borrowers to utilize. ${ }^{71}$

In many ways, then, the war had had a positive effect on the public library service in Portsmouth. Indeed, in common with many national findings, Portsmouth's library service experienced something of a boom during the period. ${ }^{72}$ While it was noted, again reflecting national trends, that the conflict had initially caused a decline in book borrowing, library officials were pleased to report that lending figures had quickly returned to normal. In fact, as the war progressed, Portsmouth's librarians noticed a significant increase in both library users and the number of books borrowed, describing a 'buoyancy of issues' that had increased 'year by year. ${ }^{\text {.73 }}$ Indeed, while in 1940 issues had reached $1,261,000$, by 1943 they were reported to have 'soared to $1,483,000{ }^{\prime} \cdot{ }^{74}$ In July 
1943, meanwhile, it was announced that borrowing had reached a 'record for peace or war' and that some borrowing records had been 'broken more than once'. ${ }^{75}$ A year later, that figure had jumped again; with officials reporting that issues were "higher than ever before recorded. ${ }^{76}$ Nationwide, library authorities were similarly reporting to MassObservation that, after an initial decline, book borrowing had far surpassed pre-war borrowing figures. ${ }^{77}$ In Derby, librarians likewise reported that after an initial dropping off in user numbers, the service had recovered and been 'very busy' ever since, with more than twice the usual number of new readers joining a library in the month following the start of the war. ${ }^{78}$

There were a few occasions when, nationally, borrowing habits took a significant dip, but these were mainly located in areas heavily affected by enemy bombing. In Portsmouth, for example, it was noted that borrower numbers dropped dramatically during peak moments of the blitz, with a particular low point noted in June 1941, shortly after one of the biggest bombing raids, when only 59,000 books were issued..$^{79}$ Evidence such as this serves as a salutary reminder of the effect of the war on the home front, revealing how the attitudes and behaviours of people living through the conflict could be shaped by it. In fact, in the same report that reflected on the positive effects of the war on public library usage, Portsmouth's library officials also reported on the damage the air raids could inflict on the library infrastructure and, ultimately, the city's inhabitants who had been caught up in their destructive aftermath. ${ }^{80}$ Indeed, one particular bombing raid in January 1941 had a devastating impact on one of the city's major libraries, Carnegie branch library, located in the working-class district of Fratton, when it was struck by a bomb. As reported in The Portsmouth Reader, the library service was quickly resumed, 
with stock being brought in from other libraries around the city, but the way in which the bombing raid and its impact was discussed in the in-house magazine reveals much about the fragile emotional state of the city's inhabitants (and, indeed the frame of mind of the individual writing the report too). ${ }^{81}$

While emphasising that the city's library service had continued to function despite the dire situation it faced, and while praising the speed in which normal service was resumed, the language contained in the library officials' reports offers a glimpse into the mindset of the city's residents and suggests that tensions were running high. In a report written shortly after the bombing raid, the library official jubilantly declared that the service's 'major casualty, Carnegie branch library, [was] ready for opening in just over a week. ${ }^{82}$ At no time in the report was the raid mentioned by name. Instead the January 1941 raid was described as 'the January happenings. ${ }^{83}$ A report written the following year again omitted mentioning the blitz by name. Instead, the heavy bombing raids of 1940 and 1941 were referred to as an 'awkward period. ${ }^{84}$ Clearly, the traumatic conditions of the blitz period were something that could only be referred to by an alternative name, suggesting that Portsmouth's residents were still recovering from the devastation they caused. It was only much later, in October 1943, when all the major bombing raids had ended, that library officials felt able to reflect honestly on that 'awkward' period. In an article entitled 'Glancing Backward: 1939-1943' one library official thus noted:

Perhaps the most discouraging morning of all this period was January $11^{\text {th }}, 1941$. There was no heat, no light and no guiding precedent, while at the same time 
problems were mounting up thick and fast. This is a convenient point to mention a few facts about Carnegie. It was a depressing sight. There were rows of charred ashes which had once been books; cases were twisted at grotesque angles, and hardly anything was in its accustomed place. [Clearing up was] most depressing work. ${ }^{85}$

This passage reveals that not only did library officials struggle to maintain a library service after the raid, but that the whole infrastructure of the city was under threat, with the report writer's comments revealing that Portsmouth's civic leaders demonstrated very little knowledge in how to proceed in such dire circumstances, a factor which, as noted by Brad Beaven and John Griffiths, often resulted in a fall in civilian morale. ${ }^{86}$ Interestingly, apart from complaining about civic authorities who had 'adopted panic measures' at the start of the war, the city's library officials remained quiet (in public at least) about any dissatisfaction they may have felt with Portsmouth's civic leaders, but they were always keen to reassure readers that they would do their utmost to keep the service functioning. ${ }^{87}$

Indeed, in order to maintain a sense of normality during wartime, Portsmouth's library officials worked relentlessly to keep their public libraries operating smoothly. Despite difficult conditions, and a lack of experience in dealing with the worst of the enemy's attacks on the city, their actions ensured the service continued to play an important part in the war effort, encouraging the city's inhabitants to use its facilities to assist in their readiness for wartime conditions. These trends were echoed across the country, where civic leaders and library authorities worked together to promote the 
appropriate use of public libraries as a wartime duty. While the majority of the country's citizens wanted to use their leisure time to escape from the pressures of the conflict, a great many also recognised that they could utilize the service's facilities in order to fulfil their wartime duties, particularly in areas of strategic importance such as Portsmouth. In fact, as this article has shown, Portsmouth's library officials identified the service as at the forefront of the war effort, and regularly encouraged the city's inhabitants to make use of it. Reflecting on the growing importance of the role the city's libraries played in wartime in the autumn of 1943 , library officials were thrilled to announce that the service had 'become an integral part of the City's life,' noting that they were 'continuously extending their contacts into many allied spheres of influence. ${ }^{88}$ Therefore, while the war had caused much disruption, including putting on hold prewar plans for the modernization of the service, on the whole Portsmouth's public libraries benefitted from the effects of the war, regularly breaking lending records across the years of the conflict. ${ }^{89}$ The benefits for wider society were equally significant, with the city's inhabitants profiting from the actions of those individuals who desired to promote reading as a form of wartime instruction.

\section{Borrowing habits and reading tastes}

While Portsmouth's library officials, along with library authorities up and down the country, continued to coordinate the service's activities in order to aid the "National Cause' - which generally meant championing 'technical and instructional' books - they did acknowledge that in order to bolster the people's 'spirits' they also needed to provide a significant amount of fiction titles..$^{90}$ Therefore, while it was the public's increased use 
of libraries for borrowing educational material that satisfied them most, a slight change in attitude among librarians and publishing trade personnel towards the public's preference for 'light' fiction can be perceived. ${ }^{91}$ These conflicting attitudes are summed up well by one Mass-Observation's report writer thus:

We have noted about the way in which some, who find difficulties and strains in reading nowadays, have turned to lighter reading than before. This movement is likely to be transitory and temporary, disappearing when the wartime pressures which produce it disappear; the tendency towards reading increasingly serious books, on the other hand, is a voluntary mental act, not enforced or required by any external conditions, and for this reason is likely to continue and even to increase. In view of all the difficulties and pressures of wartime, the very fact that there has been any movement in this direction [towards 'serious' reading] is in itself an astonishing tribute to the stamina of Britain and to the growing awareness in the public mind of the seriousness of our situation as a civilisation, and of the vast issues that face us, not only in winning the war, but in winning the peace. ${\text { (emphasis in original })^{92}}^{92}$

Of course, most telling in these comments is the continuation of the long-standing desire to encourage the reading of 'serious' matter, not fiction, and in particular not 'light' fiction. However, they do reveal how the public's tastes were expected to fluctuate as the war continued. What was not expected, it seems, was that the public's desire for more 'serious' material would be as short-lived as it was. 
Initially, and as was expected, the war stimulated demand for books that would help people's war preparedness. Publisher George Allen and Unwin Ltd, for example, praised the growth of a reading public seeking 'a more intelligent alternative' to works of fiction at the beginning of the war. ${ }^{93}$ The publisher listed books such as Mathematics for the Million and Science for the Citizen as the new type of reading material being demanded from an 'ever-growing' reading public, and were pleased to note that they had received correspondence from 'working-class people who have borrowed those books from public libraries and worked their way through them.' (emphasis in original) ${ }^{94}$ George Allen and Unwin Ltd cautioned librarians that providing such material called 'for more intelligence than the handling of light fiction,' but they remarked that they had no doubt public library officials could respond to, what they perceived to be, the changing demands of the reading public towards more serious material. ${ }^{95}$

Research conducted by Mass-Observation similarly revealed that while fiction remained highly popular during the whole of the war period, the demands of the conflict instigated a shift towards books that could aid the war effort, particularly at its start. As one report writer noted, the war had caused a significant increase in the demand for books of a technical nature - on 'aeronautics, navigation, etc.' - by 'young men expecting to be called up. ${ }^{96}$ Other non-fiction book borrowing also increased initially, with the report writer noting a growth in lending of 'political and sociological works, and an appreciable increase in books on philosophy, history, travel and biography.' ${ }^{97}$ In conducting their research, Mass-Observers had interviewed a large number of public librarians, all of whom had confirmed that the borrowing of non-fiction books had been most affected at the beginning of the war, confirming that books on 'international relations, current 
affairs, and conditions in Germany' had witnessed a significant increase in lending rates. ${ }^{98}$ These librarians also universally reported that the book which had attracted the highest borrowing figures immediately after the declaration of war was Adolf Hitler's Mein Kampf. ${ }^{99}$ Librarians in Derby had similarly noted an increased curiosity surrounding Hitler's autobiographical treatise at the beginning of the war, reporting to the local daily newspaper in October 1939:

Although there is a keen demand at Alfreton County Library for light reading, such as thrillers and "Wild West" stories, the taste of borrowers has recently shown a marked inclination for Hitler's "Mein Kampf" and other books about Germany, and for volumes dealing with the defences of Britain. ${ }^{100}$

Clearly, many people in British society wanted to use their public libraries to gain further insight into the mind of the German war leader and his homeland - and also learn how to defend themselves from the threat across the continent.

The trend towards reading more serious literature was nationally short-lived, however, and by January 1940 librarians reporting to Mass-Observation remarked that the lending of these types of book had begun to diminish. ${ }^{101}$ Library officials noted that most visitors to the country's public libraries wanted to use their reading material to escape from the horrors of the war. As the war progressed, then, borrowing trends shifted away from educational or instructional titles linked to the current conflict towards what was considered to be more escapist fare, particularly 'light' fiction. In fact, as early as 
March 1940 one report writer noted that the most popular type of book borrowed was the novel, and that, of these, it was the 'lighter type of fiction' that predominated. ${ }^{102}$ By April 1942, Mass-Observation confirmed that '[a]bout 75\% [of borrowers] read light novels and thrillers.' ${ }^{103}$ While undertaking interviews with readers as they exited libraries (both public and commercial), researchers found that borrowers' responses proved without doubt that 'the place of light fiction and thrillers is still assured,' despite the 'definite changes in reading' of more serious fare that had taken place since the war started. ${ }^{104}$ '[T]he trend in reading is at present,' the observer noted, 'towards biography, thrillers and "all types" among women, as well as a large proportion of fiction; and towards travel books, thrillers, educational and political, and adventure stories, in addition to general fiction among men. ${ }^{105}$ Therefore, while a growing number of educational volumes were being utilized, the vast majority of readers still wanted access to material that removed them, mentally at least, from the conflict.

Interestingly, borrowing patterns in the city of Portsmouth slightly contradict the national findings of Mass-Observation. While Portsmouth's library authorities did report a similar decline in some 'serious' titles in the January 1940 edition of The Portsmouth Reader, they also noted an increase in many other titles that were related to the wartime situation. Therefore, while they reported that library users showed 'no interest' in books on Poland, that 'international relations' titles were 'being read less,' and that there was a similar 'falling off in the popularity of books on the defence of this country,' Portsmouth's library officials noted that 'histories of the Great War' were 'rapidly coming into favour again,' while 'naval histories of all periods' and '[b]ooks on Germany' were 'in great demand,' with Mein Kampf recorded as 'the most popular book 
on the reserve list. ${ }^{106}$ In a summary of borrowing trends after the first seven months of 1941, meanwhile, Portsmouth's library officials believed that more books dealing with the current war were required, and recommended a number of volumes covering the conflict, six of which had a naval theme, including A.D. Divine's Behind the Fleets, ${ }^{107}$ Captain Frank H. Shaw's Stirring Deeds of Britain's Naval Might, and Bernard Stubbs's The Navy at War. ${ }^{108}$

The popularity of books about the navy in a major naval city like Portsmouth is perhaps predictable. Indeed, library officials noted that the appeal of such titles was the direct result of 'the part being played by the navy at present. ${ }^{109}$ Not surprisingly, these findings correlate well with the success of naval titles in other popular cultural forms of the period. ${ }^{110}$ However, the increased lending of other 'serious' titles reveals differences in taste that must reflect the pivotal role that Portsmouth's inhabitants expected to play during the conflict. The preference for books about the First World War and Britain's naval history may also expose an emotional response from Portsmouth's library users, suggesting that the local population was using its reading material to gain confidence and reassurance. After all, despite the appalling nature of the earlier conflict, Britain had emerged victorious. The Royal Navy, meanwhile, was habitually held in high esteem across the country and was regularly utilized in popular culture to celebrate Britain's imperial might and bolster a sense of national pride in times of severe distress. ${ }^{111}$

While lending patterns at Portsmouth's public libraries do reveal disparities with national trends regarding the borrowing of educational fare, there were similarities in book loaning trends that reveal the service was being utilized for more recreational purposes too: fiction reading, for example, continued to remain popular in the city. 
Indeed, as with national lending patterns, the borrowing of fiction titles grew significantly as the war progressed. Therefore, whereas in 1942 Portsmouth's library authorities could triumphantly claim that 'the proportion of adult fiction issues at the Central Library was only $55 \%$, a figure which surely gives lie to any theory that libraries chiefly distribute novels!,' by late-1943 it was reported, somewhat reluctantly, that '[n]aturally fiction issues have been heavy. ${ }^{112}$ There was some recognition that this was to be expected due to the continued strains caused by the lengthy conflict, but library officials were keener to stress that the provision of fiction could, like the lending of educational books, be classified as playing an important part in the war effort. One library official thus noted:

[I]t can again be emphasized that there is no particular need to apologise for this [the increased lending of fiction titles] or attempt to explain it away. Doctors, psychologists, statesmen and even librarians have admitted to an appalling taste in light literature. The truth is of course that in times of stress and strain the reading of novels can be a very great help, and as long as the reading matter is not definitely harmful, there seems no cause to wonder at this. Indeed, it may be true to say that the provision of good fiction has been a very essential part of the war contribution of public libraries when one considers the quite unprecedented strain and worry placed upon so many thousands of the community. [...] Public libraries and museums properly planned and administered occupy a very important part in the affairs of the community, and recent experience tends to prove this point. Whatever sort of new world will arise from the literal ashes of the old, it is pretty certain that libraries and museums can make a vital contribution to it. ${ }^{113}$ 
For Portsmouth's library authorities, then, providing a plentiful supply of fiction titles was in itself a form of 'war service'. The key point, of course, was that the type of fiction provided was 'good'.

Gleaning the pages of The Portsmouth Reader, where the books added each month to the city's libraries were listed, reveals that a number of well-respected fiction writers were stocked, including J.B. Priestley, Hugh Walpole and H.G. Wells. Priestley, who was a regular broadcaster during the war, had four novels added, as did Walpole, while two of Wells' books were included. ${ }^{114}$ By far the most stocked author during the war, however, was the prolific Austrian-born novelist Vicki Baum, who had seven books added between January 1940 and October $1945 .{ }^{115}$ Baum had been a best-selling author since the publication of Helene in 1928, and her style of writing was clearly expected to be popular with the city's library users. ${ }^{116}$ Other highly-popular novelists who had a significant number of works added in the period were Neil Bell, best known for his futuristic novels (five books added); Canadian author Mazo de la Roche (also five), who was best known for his Whiteoak Chronicles (also known as the Jalna Series); romantic novelist Dornford Yates (four); and romantic adventure writer Jeffery Farnol (four). ${ }^{117}$ Many authors had three novels added, including romantic novelists Warwick Deeping and Compton MacKenzie; while an even greater number had two works included on the 'Fiction' lists, including occult novelist Dennis Wheatley. ${ }^{118}$ Unfortunately, there is no record of how many times these books were loaned, nor indeed whether they were actually borrowed at all - and the articles within the in-house magazine do not reveal these details either (tellingly, only educational and instructional texts are ever mentioned) 
- but the fact that these authors' works were regularly obtained suggests that they were expected to be borrowed in good numbers. In fact, all of these novelists had books added to every one of the city's six libraries (many other authors' works were only stocked at Central Library, located near Portsea ward), so they were clearly expected to be wellborrowed across the city.

Such an eclectic range of novels reveals that the tastes of Portsmouth's readers were expected to be quite varied, and these acquisition patterns suggest that library officials were keen to respond to the tastes of as broad a range of readers as possible, male and female, young and old. ${ }^{119}$ Indeed, all of these novelists had attracted a significant following across the country, so Portsmouth's library officials were ensuring that the 'war service' they provided in terms of stocking fiction titles - from 'light' novels to more challenging fare - would be a successful one. Along with providing instructional, educational and technical books, then, these library officials were increasingly willing to include in their stocks the types of fiction that allowed their readers some respite from the stresses of the war.

\section{Conclusion}

Local government involvement in people's leisure participation increased significantly during the Second World War. However, while across Britain civic authorities' interest in people's behaviours intensified as a result of the war, in places of strategic significance, such as the naval city of Portsmouth, their interest peaked even further, and civic elites responded by extolling the great efforts they and the city's inhabitants were making as part of their wartime duties. Therefore, while the whole of British society was expected to 
adapt its leisure activities as part of the war effort, local variances ensured that for some of Britain's inhabitants those expectations rose still further. All of British society may have been involved in the war effort, but as this article has shown, in areas deemed by local officials to be at the forefront of the conflict, that involvement was seen as even more crucial to the country's achievements in the war.

By charting the activities of Portsmouth's public library authorities, this article has revealed the important role civic leaders played in trying to shape society's wartime reading habits. In common with many library services, not just nationwide, but internationally too, Portsmouth's civic and library authorities recognized the benefits a well-run and stocked service could have, not just for recreational purposes, but educational ones too. As research by the Mass-Observation movement found, an 'efficient, lively library which makes itself known and felt in a district' had countless benefits for local communities, not least affording them 'a form of education. ${ }^{120}$ As part of the war effort Britain's citizens were asked to fight, dig and save for victory. In Portsmouth, the city's library officials desired that they read for victory too, whether that by borrowing fiction to raise morale, or delving into instructional and technical texts to educate themselves in wartime citizenship.

Under the extremely demanding conditions of the Second World War, Portsmouth's public library service fulfilled the function for which it had originally been intended. Of course, across Britain public libraries were similarly being utilized for their educational potential, but Portsmouth's port-side location and military significance meant that the pressures placed on both the city's library authorities and inhabitants to use the service for that reason were felt to be much greater. Such findings reveal that the 
distinctive urban and maritime identity of this port city played a major role in helping to shape its civic and leisure cultures during the Second World War, opening up for question how commonly this occurred not just within Britain, but internationally too.

\section{Notes:}

1 'Facing the Facts', The Portsmouth Reader, April 1940, 4.2, 20-21. All public library records for Portsmouth are located in Portsmouth History Centre and Records Office, Norris Central Library, Portsmouth, UK.

${ }^{2}$ Robert James, Popular Culture and Working-Class Taste in Britain, 1930-39: A round of cheap diversions? (Manchester, 2010), 69-70.

${ }^{3}$ One of the aims of the Ministry of Information, which was set up after the declaration of war, was to promote British culture, which was used as an example of 'what we were fighting for'. See Ian McLaine, Ministry of Morale: Home Front Morale and the Ministry of Information in World War II (London, 1979). The Army Bureau of Current Affairs was established in 1941 by William Emrys Willaims to help educate and raise morale among army personnel. See Penelope Summerfield, 'Education and Poilitics in the British Armed forces in the Second World War', International Review of Social History, 26.2, 1981, 133-158.

${ }^{4}$ Brad Beaven, Leisure, Citizenship and Working-Class Men in Britain, 1850-1945 (Manchester, 2005), 211. For further reading on the issue of wartime citizenship, see Toby Haggith, 'Citizenship, Nationhood and Empire in British Official Film Propaganda, 1919-45', in Richard Weight and Abigail Beach (eds), The Right to Belong: Citizenship and National Identity in Britain 1930-1960 (London, 1998), 36-58; David Matless, 'Taking Pleasure in England: Landscape and Citizenship in the 1940s', ibid, 181-204; Sian Nicholas, 'From John Bull to John Citizen: Images of National Identity and Citizenship on the Wartime BBC', ibid, 36-58.

${ }^{5}$ See, for example, James Chapman, The British at War: Cinema, State and Propaganda, 1939-1945 (London, 1998); Richard Farmer, The Food Companions: Cinema and Consumption in Wartime Britain, 1939-45 (Manchester, 2011); Ina Zweigniger-Bargielowska, Austerity in Britain: Rationing, Controls and Consumption, 1939-1955 (Oxford, 2000). For a detailed analysis of the long-term effects of the war, see Mark Clapson and Peter Larkham (eds). The Blitz and its Legacy: Wartime Destruction to Post-War Reconstruction (Farnham, 2013).

${ }^{6}$ Some important work has been written. See, for example, Brad Beaven and John Griffiths, 'The Blitz, Civilian Morale, and the City: Mass-Observation and Working-Class Morale in Britain 1940-41', Urban History, 26, 1, 1999, 71-88, which investigates the effects of regional variations in various aspects of wartime life, such as leisure, work, local government and civilian morale. 
${ }^{7}$ As one of the main propaganda media, British cinema has attracted significant scholarship, including Anthony Aldgate and Jeffrey Richards, Britain Can Take It: The British Cinema in the Second World War (Edinburgh, 1994); Chapman, British at War; Richard Farmer, Cinemas and Cinemagoing in Wartime Britain: The Utility Dream Palace (Manchester, 2016); Farmer, Food Companions; F. Thorpe and Nicholas Pronay, British Official Films in the Second World War, (Oxford, 1980); and James C. Robertson, 'British Film Censorship Goes to War', Historical Journal of Film, Radio and Television, 2.1, 1982, 49-64.

${ }^{8}$ Ronald Sturt and Mona E. Going have investigated hospital libraries in England and Wales during the First World War, while Ilkka Mäkinen has looked at the Finnish equivalent during the Second World War. See Ronald Sturt and Mona E. Going, 'Hospital Libraries in England and Wales: A history', in Mona E. Going (ed.), Hospital Libraries and the Disabled (London: 1973), 21-66, and Ilkka Mäkinen 'Libraries and Reading in Finnish Military Hospitals during the Second World War', Library Trends, 55.3, 2007, 536550. Terry Teachout, meanwhile, has researched the paperbacks provided to American service personnel known as Armed Services Editions - during the Second World War. See Terry Teachout, 'How the Second World War Made America Literate', Commentary, 139.6, 2015, 58-60. See also Debra Mulligan, 'Reading and the Second World War, 1941-1960', in Sara Quay and Gabrielle R. Watling (eds), Cultural History of Reading (Santa Barbara, 2008), 241-274.

${ }^{9}$ Mäkinen 'Libraries', 539; Teachout, 'How the Second World War Made America Literate', 59.

${ }^{10}$ The article thus contributes to the 'people's war' debate initiated in the late-1960s by Angus Calder's The People's War. Britain 1939-45 (London, 1969). Calder challenged earlier histories of the war in which it was argued that British society unified under wartime conditions, leading to social and gender levelling. See, for example, Richard Titmuss, History of the Second World War: Problems of Social Policy (London, 1950) and Arthur Marwick, The Home Front (London, 1976). Calder cemented his revisionist position with The Myth of the Blitz (London, 1991), and subsequent scholars have likewise continued along this theme. See, for example, Donald Thomas, An Underworld at War: Spivs, Deserters, Racketeers and Civilians in the Second World War (London, 2003); M.J. Trow, War Crimes: Underworld Britain in the Second World War (Barnsley, 2008); and Stuart Hylton, Careless Talk: The Hidden History of the Home Front 1939-1945 (London, 2010).

${ }^{11}$ See David Vincent, 'Reading in the Working-Class Home, in J.K. Walton and James Walvin (eds), Leisure in Britain, 1780-1939 (Manchester, 1983), 207-226; 213. See also Jonathan Rose, The Intellectual Life of the British Working Classes (London, 2001), 58-59.

${ }^{12}$ Jeffrey Hill, Sport, Leisure and Culture in Twentieth-Century Britain (Basingstoke, 2002), 167.

${ }^{13}$ Alistair Black, The Public Library in Britain, 1914-2000 (London, 2000), 54-56.

${ }^{14}$ In a report looking back at the service's early years, officials discussed its long-standing edifying qualities. See 'Books and Information', City of Portsmouth Libraries and Museums: An Account of the Year's Work 1940-1941.

15 'Fifty Years of Service - 1905-1955: Golden Jubilee of the Opening of the Central Library $2^{\text {nd }}$ December 1905’, 8. Storage Box: 1905-1991, Peterborough Public Library Archive, Peterborough, UK. 
${ }^{16}$ Officials from both government departments were cited in The Portsmouth Reader, 5.1, 1941-1942, 1.

${ }^{17}$ Mass-Observation Archive (hereafter M-OA), 'Books and the Public: A Study of Buying, Borrowing, Keeping, Selecting, Remembering, Giving and Reading Books', File Report 1332, July 1942, 63.

${ }^{18}$ William, G. Easthope (ed.), Smitten City: The Story of Portsmouth under the Blitz (Portsmouth, 1945), 4.

${ }^{19}$ Ordnance Survey maps of Portsmouth are located in Portsmouth History Centre and Records Office, Norris Central Library, Portsmouth, UK.

${ }^{20}$ Peter Haskell, 'A Changing City', in John Webb, Sarah Quail, Peter Haskell and Richard Riley (eds.), The Spirit of Portsmouth: A History (Chichester, 1989), 169-176; 169.

${ }^{21}$ Beaven and Griffiths, 'The Blitz, Civilian Morale and the City', 79.

${ }^{22}$ Beaven, Leisure, 221-224.

${ }^{23}$ Editorial, The Portsmouth Reader, January 1940, 4.1, 1.

${ }^{24}$ Ibid.

${ }^{25}$ In Manchester, for example, the first public library opened in September 1852. See 'History of Central Library', http://manchester.gov.uk/info/500138/central_library, last accessed 26 May 2016.

${ }^{26}$ See comments published in 'Portsmouth is Now Library Conscious: A Review of 60 Years' Work in the City', Evening News (Portsmouth), 30 May 1944, p. 2. See also Adele Roper, 'The Development of Public Libraries in Portsmouth 1853-1934', University of Portsmouth dissertation, (n.d.), 5.

${ }^{27}$ Roper, 'The Development of Public Libraries in Portsmouth', 9-12.

${ }^{28}$ Ibid.

${ }^{29}$ See City of Portsmouth Fifty-Third Annual Report on the Public Libraries and Museums, 1936-1937.

${ }^{30}$ See City of Portsmouth Forty-Sixth Annual Report on the Public Libraries and Museums, 1929-1930 in which it was noted that the lists provided in the newspaper would be 'prove of great assistance to readers'.

${ }^{31}$ Editorial, The Publishers' Circular and Booksellers' Record, 1 October 1932, 362.

${ }^{32}$ Eric R. Stone, The Publishers' Circular and Booksellers' Record, 26 March 1938, 449. See also letter from Barbara R. Kyle, a Senior Assistant of Fulham Public Libraries.

${ }^{33}$ In 1931 Cowles printed an article in a local library bulletin displaying an acceptance of the growth in reading for 'entertainment and recreation only' that was picked up by the editor of The Publishers' Circular and Booksellers' Record and used to attack Cowles for his liberal views. 'What is the function of the public library?', The Publishers' Circular and Booksellers' Record, 18 April 1931, 466. Many contributors to the trade paper concurred with the editor's stance and roundly criticised Cowles' viewpoint. See, for example, letter from Lionel W. Jones, ibid., 27 June 1931, 785. See also 'Borrowing versus buying, ibid., 29 August 1931, 233.

${ }^{34}$ Frederick J. Cowles, 'Books in wartime', The Publishers' Circular and the Booksellers' Record, 28 October 1939, 426.

${ }^{35}$ Frank A. King, 'Readers Want to Escape from the War', The Publishers' Circular and Booksellers' Record, 9 December 1939, 571-572.

${ }^{36}$ Editorial, The Portsmouth Reader, vol. 4, no. 1, January 1940, 3. 
${ }^{37}$ George Allen and Unwin Ltd., “'Escape” Books', The Publishers' Circular and Booksellers' Record, 16 December 1939, 592.

38 'Library service in time of war', The Library Association, Derby Public Library Minutes, Derby Local Studies Centre, Derby.

39 'Carry On, Booksellers!', The Bookseller, 7 September 1939, 311.

40 'Books and the Blackout', The Publishers' Circular and Booksellers' Record, 30 December 1939, 619.

${ }^{41}$ Ibid.

${ }^{42}$ M-OA, 'Books and the Public', 71.

${ }^{43}$ Mass-Observation research did reveal that the war had affected who read, but the levels of readers had not been reduced.

${ }^{44}$ The wartime boost to reading was also noted in Finland and America, where publishers and librarians recognised the gains to be made by capturing a public eager to seek an escape from the conflict. See Mäkinen 'Libraries', 545, and Teachout, 'How the Second World War Made America Literate', 58.

${ }^{45}$ M-OA, 'Books and the Public', 71-72.

${ }^{46}$ See, for example, The Portsmouth Reader, January 1940, 4.1, 1-3; ibid., January 1941, 5.1 1; ibid., October 1941, 5.4, 37; ibid., April 1942, 5.6, 61. The importance of libraries in the post-war period was also discussed. See, for example, ibid., July 1944, 7.3, 41 and July 1945, 8.3, 25.

${ }^{47}$ M-OA, Kathleen Box, 'Wartime Reading', File Report 47, 1940, 5-6.

${ }^{48}$ MO-A, 'Books and the Public', 15.

${ }^{49}$ Haskell, 'A Changing City', 169-176.

50 'Glancing Backwards: 1939-1943', The Portsmouth Reader, 6.4, October 1943, 45.

${ }^{51}$ See, for example, The Portsmouth Reader, October 1943 when 29 new fiction titles were listed, along with a large number of books in other categories.

${ }^{52}$ See The Portsmouth Reader, July 1942, 7.3, 77.

${ }^{53}$ John Hilton's letter was reproduced in The Portsmouth Reader, April 1940, 4.2, 19.

${ }^{54}$ See The Portsmouth Reader, 5.1, January 1941, 1.

55 The publication was unnamed in the report. See The Portsmouth Reader, 6.3, July 1943, 29.

${ }^{56}$ As transient communities, service personnel would not usually have access to books from local public libraries.

${ }^{57}$ The Portsmouth Reader, 4.3, July 1940, 31.

${ }^{58}$ Ibid., 5.3, July 1941, 26. See also 7, July 1942, 78.

${ }^{59}$ Ibid., 5.4, October 1941, 38.

${ }^{60}$ Ibid., 6.2, April 1942, 61.

${ }^{61}$ Other titles included: Mines, Advanced Mathematics, Calculus of Observations, Television, Valve Oscillators, Cathode Rays, Wireless Mathematics, Colour Sensitive Materials, Carburetors, Medical Psychology, Aero-Dynamics, Infra-red Rays, and Diesel Engines. Ibid. 
${ }^{62}$ Ibid., 6.3, July 1943, 33.

63 'Glancing Backwards', 47.

${ }^{64}$ The Portsmouth Reader, 6.1, January 1943, 1.

${ }^{65}$ Ibid.

${ }^{66}$ Editorial, The Publishers' Circular and Booksellers' Record, 23 December 1939, 601-602.

67 'They Planned a World', The Portsmouth Reader, 7.1, January 1944, 5.

${ }^{68}$ The McColvin Report was viewed as the 'Beveridge Plan' for public libraries. Written by Lionel R.

McColvin in 1943, the report focused on the postwar role of British Public Libraries. The Library

Association and other organisations assisted in compiling the report. See Carleton B. Joeckel, 'A Postwar

Plan for British Public Libraries: The McColvin Report', ALA Bulletin, 37.5, May 1943, 163-165.

${ }^{69}$ The Portsmouth Reader, 7.3, July 1944, 32.

70 'The Restless Continent', The Portsmouth Reader, 8.2, April 1945, 14.

71 'The British Empire', The Portsmouth Reader, 8.4, July 1945, 38.

${ }^{72}$ For a national perspective on the initial decline and then upward surge of public library issues, see M-OA

'Book Reading in Wartime: Report on Material Obtained from Publishers, Book Clubs, Libraries and

Booksellers', File Report 46, March 1940, 27.

73 'Glancing Backwards', 44.

${ }^{74}$ Ibid.

${ }^{75}$ Ibid., 6.3, July 1943, 30.

${ }^{76}$ Ibid., 7.3, July 1944, 29.

${ }^{77}$ M-OA, 'Book Reading in Wartime', 27.

78 'Wartime Reading', Derby Daily Telegraph, 11 October 1939, 2.

79 'Glancing Backwards', 44.

${ }^{80}$ Ibid.

${ }^{81}$ Ibid. See also 5.2, April 1941, 14.

82 'Glancing Backwards', 44..

${ }^{83}$ Ibid.

${ }^{84}$ Ibid., 5.7, July 1942, 76.

85 'Glancing Backwards', 46.

${ }^{86}$ Beaven and Griffiths, 'The Blitz, Civilian Morale and the City', 79.

${ }^{87}$ The Portsmouth Reader, 5.2, April 1941, 14.

88 'Glancing Backwards', 44.

${ }^{89}$ The Portsmouth Reader, 6.3, July 1943, 30. Library officials noted that plans for a new Central Library had been drawn up but had to be set aside because of the war. 'Glancing Backwards', 43.

${ }^{90}$ MO-A, 'Books and the Public', 182.

${ }^{91}$ Robert James, “"Literature acknowledges no boundaries”: Book Reading and Social Class in Britain, c. 1930-1945', Journal of Social History, 51:1, 2017, 80-100. 
${ }^{92}$ MO-A, 'Books and the Public', 182-183.

93 “"Escape” Books', 592.

${ }^{94}$ Ibid.

${ }^{95}$ Ibid.

${ }^{96}$ M-OA, 'Book Reading Survey: Interim Report, March-April 1940', File Report 1222, April 1940, 7.

${ }^{97}$ Ibid., 8.

${ }^{98}$ M-OA, 'Book Reading in Wartime', 28.

${ }^{99}$ Ibid.

100 'Wartime Reading', Derby Daily Telegraph, 11 October 1939, 2.

${ }^{101}$ MO-A, 'Book Reading in Wartime', 28.

102 Ibid., 27.

${ }^{103}$ M-OA, 'Book Reading Survey', 8.

${ }^{104}$ Ibid.

${ }^{105}$ Ibid., 9-10.

106 The Portsmouth Reader, 4.1, January 1940, 3.

107 The full title of A.D. Divine's volume is, Behind the Fleets: a first-hand account of the duties and exploits of the convoys, the Dover patrol, the minesweepers and the other subsidiary fleets.

108 The Portsmouth Reader, 5.1, 1941-1942. Bernard Stubbs was to be lost in the sinking of HMS Hood in 1941. See 'Battle Cruiser Hood', http://www.hmshood.com/crew/memorial/s/StubbsCFB.htm, last accessed 21 May 2016.

${ }^{109}$ The Portsmouth Reader, 4.1, January 1940, 3.

${ }^{110}$ For example, films of or about the sea were continually booked at one of the city's cinemas throughout the first half of the twentieth century, while music hall venues regularly featured naval fare. See Robert James, 'Cinema-going in a Port Town, 1914-1951: Film Booking Patterns at the Queens Cinema, Portsmouth', Urban History, 40:2, 2013, 315-335, and Melanie Bassett, 'The Royal Dockyard Worker in Edwardian England: Culture, Leisure and Empire', unpublished University of Portsmouth PhD thesis, 2014, 136-139.

${ }^{111}$ Robert James, “'If there's one man that I admire, that man's a British tar”: Leisure and Cultural NationBuilding in a Naval Port Town, c. 1850-1928', in Brad Beaven, Karl Bell and Robert James (eds), Port Towns and Urban Cultures: International Histories of the Waterfront, c. 1700-2000 (London: 2016), 179199.

112 The Portsmouth Reader, 7.3. July 1942, 75, and 'Glancing Backwards', 48.

113 'Glancing Backwards', 48-49.

${ }^{114}$ For additions of Priestley's work see The Portsmouth Reader, 4.1, January 1940, 16; 5.7, October 1942, 101; 6.4, October 1943, 55 and 8.3, July 1945, 35. For Walpole see ibid., 4.1, January 1940, 16; 5.1, January 1941, 11; 5.5, January 1942, 59 and 6.1, January 1943, 13. For Wells see ibid., 5.1, January 1941 and 11, 5.6, April 1942, 73. 
${ }^{115}$ For acquisitions of Baum's work see ibid., 4.1, January 1940, 16; 5.1, January 1941, 11; 5.5 January 1942, 59; 6.1, January 1943, 13; 6.2, April 1943, 27; 7.4, October 1944, 52 and 8.4, October 1945, 47. ${ }^{116}$ Helene was originally published as Stud. chem. Helene Willfüer. See 'Vicki Baum: Jewish Women's Archive', https://jwa.org/encyclopedia/article/baum-vicki, last accessed 11 September 2017.

${ }^{117}$ For Bell additions see The Portsmouth Reader, 5.7, October 1942, 101; 5.6, April 1942, 73; 6.3, July 1943, 41; 7.2, April 1944, 28 and 8.3, July 1945, 35. For de la Roche see ibid., 4.3 July 1940, 41; 5.1, January 1941, 11; 5.5 January 1942, 59; 5.7, July 1942, 87 and 5.8, October 1942, 101. For Yates see ibid., 4.1, January 1940, 16; 5.1, January 1941, 11; 7.2, April 1944, 28 and 8.2, April 1945, 13.

${ }^{118}$ For Deeping acquisitions see ibid., 5.3 July 1941, 36; 6.1 January 1943, 13 and 6.4, October 1943, 55. For MacKenzie see ibid., 4.3, July 1940, 41; 5.2 April 1941, 23 and 8.3, July 1945, 35. For Wheatley see ibid., 5.7, July 1942, 87 and 6.1, January1943, 13.

${ }^{119}$ Due to the city's reliance on the Royal Naval Dockyard for employment, the 'range' of readers was largely restricted to the middle and working classes. See James, Popular Culture, 177.

${ }^{120}$ M-OA, 'Books and the Public', 65. 